\title{
Magdalena Jankowska-Guściora
}

Uniwersytet Opolski

\section{Sytuacja uwięzionych kobiet w dwudziestoleciu międzywojennym}

\section{A situation of imprisoned women during the interwar period}

Streszczenie. W dwudziestoleciu międzywojennym powstał pierwszy akt prawny, który wprowadzał odrębność postępowania wobec kobiet przebywających w warunkach izolacji penitencjarnej. Dostrzeżono, że sposoby i metody wykonywania kary pozbawienia wolności wobec kobiet powinny być inne niż wobec mężczyzn. Okres dwudziestolecia międzywojennego to początek formułowania się odrębnych przepisów w tej materii. Mimo początkowego traktowania uwięzionych kobiet jako homogenicznej populacji, zaczęto zwracać uwagę na potrzebę odmiennego postępowania z więźniarkami - szczególnie brzemiennymi i karmiącymi. Następowała powolna ewolucja uwzględniająca odrębności płci w oddziaływaniach penitencjarnych, zwłaszcza w kontekście karania dyscyplinarnego, rozmieszczenia w celach mieszkalnych, zatrudnienia, wyżywienia i wyposażenia kobiet. Wprowadzone wówczas rozwiązania niewątpliwie stanowią podwaliny więziennictwa polskiego, na podstawie których kształtował się funkcjonujący dzisiaj system penitencjarny. Celem niniejszego artykułu jest ukazanie warunków życia kobiet osadzonych w polskich więzieniach w latach 1918-1939.

Słowa kluczowe: dwudziestolecie międzywojenne, uwięzione kobiety, odrębność traktowania uwięzionych kobiet, oddziaływania penitencjarne wobec kobiet.

Summary. The first legal document that introduced a distinction of treatment between imprisoned men and women was created during the interwar period. At that time, the need to differentiate the execution of the penalty methods between men and women was emphasized. This particular period initiated the beginning of formulating separate regulations related to the issue of imprisoned women. At first, they were treated as a homogeneous population. However, after some time, the need for alternative treatment of female prisoners, especially pregnant and breastfeeding, was noticed. Gradually, taking into account gender differences in the penitentiary interactions, slow evolution was taking place, especially in the context of disciplinary punishment, locating in prison cells, employment, board or permitted 
clothing. The solutions adopted at that time are considered to be the foundations of today's Polish prison system. The aim of this article is to illustrate the living conditions of women imprisoned in Polish prisons in years 1918-1939.

Key words: interwar period, imprisoned women, distinction of a treatment of female prisoners, penitentiary interactions towards women.

\section{Wprowadzenie}

Polskie więziennictwo w 2014 roku obchodziło 95-lecie istnienia. Za początek jego powstania uznaje się 8 lutego 1919 roku, kiedy to Józef Piłsudski, naczelnik państwa, wydał dekret „W sprawie tymczasowych przepisów więziennych”. Był to główny i podstawowy akt prawny determinujący działalność administracji więziennej w wolnej Polsce. W związku z odzyskaniem niepodległości przed władzami kraju stanęło wiele zadań i obszarów wymagających gruntownych reform. Problem więziennictwa był jednym z nich, oprócz konieczności odbudowy jednolitej armii, zniszczonej gospodarki czy opracowania nowego systemu prawnego. Począwszy od listopada 1918 roku, obiekty więzienne stopniowo przechodziły z rąk zaborców pod zarząd polski. Przejęcie więzień należy traktować jako początek ujednolicania więziennictwa polskiego, bowiem przez 123 lata na ziemiach polskich funkcjonowały trzy odmienne systemy penitencjarne. Więzienia różniły się architekturą, nomenklaturą, wewnętrznym zorganizowaniem, przepisami. Przejmowanie jednostek penitencjarnych odbywało się etapami. Ogółem w latach 1918-1922 od byłych zaborców państwo polskie przejęło 400 więzień, z których część znajdowała się w fatalnym stanie technicznym, z bardzo złymi warunkami socjalno-bytowymi i sanitarnymi (Migdał, Raglewski 2005, s. 123). W więzieniach panował głód i brud, brakowało żywności, ubrań oraz bielizny, a także opału do ogrzewania pomieszczeń. Z powodu braku lekarstw i właściwej opieki medycznej wśród więźniów szerzyły się choroby takie jak tyfus głodowy i gruźlica (tamże, s. 124). Na oddziale kobiecym w więzieniu Bydgoszcz Fordon słomę w siennikach wymieniono co trzy, cztery lata (Pawlak 1995, s. 19). Funkcjonujące w taki sposób więzienia bez wątpienia wymagały zmian. Ostatecznie w 1928 roku w Polsce istniało 366 więzień i aresztów, a w 1938 roku było ich 344 (Car 1997, s. 44).

Rozwój więziennictwa polskiego $\mathrm{w}$ okresie międzywojennym można podzielić na dwa etapy, które były konstytuowane swoistymi tendencjami i aktami prawnymi. Lata 1918-1928 to początek kształtowania się systemu, 
przejmowania po zaborcach jednostek penitencjarnych. W 1928 roku został wydany pierwszy akt normatywny regulujący podstawowe i najważniejsze kwestie związane z wykonywaniem kary pozbawienia wolności, ustalający zasady organizacji więziennictwa na terenie całego kraju. Wydanie Rozporządzenia Prezydenta Rzeczypospolitej z dnia 7 marca 1928 roku w sprawie organizacji więziennictwa było swoistym przełomem w dziejach międzywojennego więziennictwa (Pawlak 1990, s. 56). W założeniach nowo kształtującego się systemu penitencjarnego celem wymierzonej kary było wychowanie więźnia przez pracę i umoralnienie, przy jednoczesnym występowaniu założeń jednoznacznie wskazujących na funkcję odstraszającą od popełniania przestępstw (Urbański 1997, s. 9). Przełom polegał na zmianie sposobu wykonywania kary pozbawienia wolności z represyjnego na resocjalizacyjny (Migdał, Raglewski 2005, s. 128). Kara przestała być środkiem odwetu, jej istotę stanowiła klasyfikacja i podział więzień na różnorodne typy o odmiennej organizacji.

Drugi etap rozwoju więziennictwa przypadający na lata 1929-1939 to próba dostosowywania się polskiej penitencjarystyki do ówczesnych tendencji światowych (tamże, s. 120). W tym czasie został wydany jedyny w II Rzeczypospolitej regulamin więzienny (Rozporządzenie Ministra Sprawiedliwości z dnia 20 czerwca 1931 roku w sprawie regulaminu więziennego), a jego zapisy określały funkcjonowanie jednostek penitencjarnych. Wzbogaceniu uległy formy oddziaływania, polska myśl penitencjarna ewoluowała, utrwalając ideę i cel resocjalizacji sprzyjający poprawie skazanych. Ustawa z dnia 26 lipca 1939 roku o organizacji więziennictwa stanowiła swoiste podsumowanie teoretycznego i praktycznego dorobku polskiej, międzywojennej penitencjarystyki (Bugajski, Neymark 2005, s. 121).

Problematyka dotycząca kobiet odbywających karę pozbawienia wolności w latach międzywojennych, z uwagi na fakt uzyskania w 1918 roku przez nie praw wyborczych, jest interesująca, choć stosunkowo rzadko podejmowana przez badaczy. Dlatego też w celu przybliżenia tematyki odnoszącej się do wprowadzonych wówczas, pionierskich rozwiązań wobec uwięzionych kobiet, poniżej przedstawiono kilka istotnych, z punktu widzenia penitencjarystyki, zmian w tym zakresie.

Artykuł ma charakter teoretycznej kompilacji. Powstał w oparciu o kwerendę literatury i analizę dokumentów, a problem główny stanowiło ukazanie sposobu ewoluowania rozwiązań penitencjarnych podejmowanych wobec więźniarek. 


\section{Przestępczość kobiet w okresie dwudziestolecia międzywojennego}

Nie sposób odnieść się do sytuacji uwięzionych kobiet bez przedstawienia zjawiska przestępczości kobiecej, skutkującej uwięzieniem. Udział kobiet w przestępczości był zawsze niższy od mężczyzn z wyjątkiem przestępstwa, jakim była wówczas prostytucja (Migdał 2011, s. 84). Ustawa sanitarna z dnia 19 lipca 1919 roku regulowała kwestie dotyczące prostytucji kobiet, nakładając na nie m.in. obowiązek poddawania się kontrolom lekarskim. W latach 1922-1939 w ramach prowadzonego rejestru sanitarnego wpisywano dane każdej kobiety, która zawodowo zajmowała się prostytucją (Rabinowicz 1984, s. 37). Karalne było zakażanie chorobami przenoszonymi drogą płciową. Liczba wyroków skazujących kobiety w okresie 1924-1928 stanowiła 17-21\% ogółu wszystkich orzeczeń (tamże, s. 31). W ciągu roku od 31 tys. do 34 tys. kobiet skazywanych było za popełnienie czynów karalnych. Do najczęściej dokonywanych przez kobiety naruszeń prawa należało dzieciobójstwo i przerywanie ciąży, które nazywano przestępstwami przeciwko obowiązkowi macierzyńskiemu. Ponadto stosunkowo częściej aniżeli mężczyźni, kobiety swoimi czynami występowały przeciwko czci i moralności, dopuszczając się stręczycielstwa, nierządu oraz udziału w paserstwie (tamże, s. 32-33). Duży udział kobiet w przestępstwach przeciwko czci tłumaczono warunkami ich życia oraz właściwościami psychicznymi w okresie przekwitania, natomiast paserstwo wyjaśniano bardziej odpowiadającą kobiecej naturze chęcią zaspokojenia żądzy (tamże, s. 32).

Z dniem 1 września 1932 roku wszedł pierwszy, po odzyskaniu przez Polskę niepodległości, kodeks karny. Jego regulacje wskazywały, że matka, która zabiła dziecko podczas porodu pod wpływem jego przebiegu, podlegała karze więzienia do lat 5 . Kodeks przewidywał karę pozbawienia wolności do lat 3 dla kobiety poddającej się aborcji, natomiast osoby wykonujące aborcję lub pomagające w usunięciu płodu podlegały karze więzienia do 5 lat. Jako przestępstwo nie było traktowane przerwanie ciąży przez lekarza $z$ uwagi na zdrowie i życie kobiety lub w sytuacji, gdy odmienny stan był wynikiem nierządnego czynu na nieletniej, rezultatem przemocy lub czynu kazirodczego (Pietrzak 2000, s. 91). W przypadku przestępstw nacechowanych dużym poziomem agresji, siły fizycznej czy popełnianych pod wpływem alkoholu udział kobiet był niewielki (Rabinowicz 1984, s. 33). Pięciokrotnie rzadziej od mężczyzn dopuszczały się one kradzieży. W latach 1932-1937, czyli po zmianie kodeksu karnego w 1932 roku, zwiększeniu uległa częstotliwość stosowania kary pozbawienia wolności wobec kobiet. Pod koniec lat 
trzydziestych minionego stulecia obserwowano wzrost liczby popełnianych przez nie przestępstw związanych z fałszowaniem dokumentów i wykroczeń przeciwko przepisom dewizowym. W latach trzydziestych od 40 do 60 kobiet rocznie skazywano za fałszownie pieniędzy (Migdał 2012, s. 133-134). Morderczynie, aferzystki, malwersantki były piętnowane głównie przez ówczesną prasę, tzw. brukową, w której nagłaśniano przestępstwa przez nie popełnione. Na łamach prasy w 1934 roku stworzono profil morderczyni, opierając się na pseudonaukowych publikacjach (Janicki 2013, s. 15).

\section{Wykonywanie kary pozbawienia wolności wobec kobiet}

Mniejszy udział kobiet w przestępczości przekładał się na ich stosunkowo niewielki udział w populacji osób odbywających karę pozbawienia wolności. Nie jest znana dokładna liczba osadzonych w więzieniach przed 1926 rokiem (Pawlak 2008, s. 129-138). Wiadomo natomiast, że w 1926 roku ich udział wśród ogółu więźniów wynosił 11\%, a w 1939 - 9,4\% (Migdał 2012, s. 135). W ówczesnej polskiej penitencjarystyce nie były podejmowane rozwiązania związane $\mathrm{z}$ wykonywaniem kary pozbawienia wolności adresowane do kobiet jako do populacji skazanych ze specyficznymi potrzebami, odrębnością psychofizyczną i społeczną, wbrew temu, co ustalono na V Międzynarodowym Kongresie Więziennym w Paryżu już w 1895 roku. Powstała wówczas uchwała wskazująca na konieczność ustanowienia odrębnych praw dla kobiet pozbawionych wolności, złagodzenia wobec nich reżimu i dyscypliny więziennej (tamże, s. 135). Wytyczne dotyczyły przede wszystkim konieczności koncentrowania się na właściwościach fizjologicznych i psychicznych kobiet, przede wszystkim związanych z rolą matki. Mimo że żaden z przepisów wydanych po odzyskaniu niepodległości nie ustanawiał odrębnego wykonywania kary pozbawienia wolności wobec kobiet, to w kilku obszarach funkcjonowania w warunkach izolacji penitencjarnej uwidaczniała się odmienność płci (Gordon 1990, s. 478). Przede wszystkim kobiety karę pozbawienia wolności odbywały oddzielnie od mężczyzn. W większości więzień wyodrębniono oddziały żeńskie - obok istniejących już męskich. W Polsce funkcjonowała tylko jedna jednostka penitencjarna przeznaczona wyłącznie dla kobiet - Fordon koło Bydgoszczy (Pawlak 2008, s. 129-138). Rzetelne dane na temat oddziałów dla kobiet znaleźć można dopiero w 1939 roku w związku z opublikowaniem w Kalendarzu Informatorze Sądowym wykazu więzień (tamże, s. 129-138). Oddziały żeńskie funkcjonowały zatem w zakładach karnych w Białymstoku, Cieszynie, Grodnie, Kaliszu, Kielcach, Lub- 
linie, Łucku, Nowym Sączu, Piotrkowie Trybunalskim, Płocku, Poznaniu, Wejherowie, Radomiu, Rzeszowie, Siedlcach, Stanisławowie, Tarnowie, Wadowicach, Wilejce, Wilnie, Złoczowie i w Warszawie przy ul. Dzielnej. Ten ostatni był przystosowany do wykonywania kary wobec kobiet ciężarnych i karmiących, bowiem posiadał sale szpitalne, sale porodowe, salę żłobka (Migdał 2012, s. 141).

Z uwagi na małą liczbę skazanych kobiet, w początkowym okresie kształtowania się więziennictwa polskiego, traktowano je - wspólnie z mężczyznami, jako jedną homogeniczną populację. Po raz pierwszy w niepodległej Polsce do kobiet, w aspekcie wykonywania kary pozbawienia wolności, nawiązuje zapis zawarty w Dekrecie w sprawie tymczasowych przepisów więziennych, w którym spośród całego katalogu kar dyscyplinarnych wskazuje się na zakaz stosowania względem kobiet kary nałożenia kajdan (art. 7 - Dekret w sprawie tymczasowych przepisów więziennych (Dz. Praw nr 15 z dnia 8 lutego 1919 r. poz. 202)). Pozostałe kary takie jak m.in. nagana, post, pozbawienie pościeli na czas do jednego tygodnia, zamknięcie w samotności na czas do 6 tygodni, ściemnienie celi na czas do 2 dni, pozbawienie ulg i przywilejów przewidzianych w regulaminie więziennym czy zwiększenie ilości pracy przymusowej dotyczyły w równym stopniu wszystkich więźniów, z wyłączeniem tych, którzy nie ukończyli 17 lat, bez względu na płeć.

Obserwacja sposobu funkcjonowania skazanych kobiet w kontekście ich odmienności, szczególnie właściwości biologiczno-psychicznych, wskazała na konieczność stosowania odrębnych metod i działań resocjalizacyjnych (Migdał 2011, s. 86). W treści kolejnego przepisu wiążącego się z wykonywaniem kary pozbawienia wolności zwanego Rozporządzeniem Prezydenta Rzeczypospolitej z dnia 7 marca 1928 roku w sprawie organizacji więziennictwa znajdują się regulacje odnoszące się do odmiennego traktowania więźniów $\mathrm{z}$ uwagi na płeć. W jednym z nich jasno formułuje się odrębność osadzania więźniów płci żeńskiej od więźniów płci męskiej, co stanowi o pierwszej, najwcześniejszej zasadzie klasyfikacyjnej (art. 5 Rozporządzenie Prezydenta Rzeczypospolitej z dnia 7 marca 1928 roku w sprawie organizacji więziennictwa). Więźniarki nie mogły kontaktować się z mężczyznami odbywającymi karę. W placówkach, w których oddział żeński znajdował się w tym samym budynku co męski, zamontowano trwałą przegrodę uniemożliwiającą jakikolwiek kontakt (Pawlak 2008, s. 129-138). Ponadto kobiety były oddzielnie transportowane, wykonywały osobno różne zajęcia, np. ćwiczenia gimnastyczne (art. 89, art. 210 - Rozporządzenie Prezydenta Rzeczypospolitej z dnia 7 marca 1928 roku w sprawie organizacji więzienni- 
ctwa). Rozdzielenie kobiet i mężczyzn dotyczyło również wspólnych nabożeństw czy pomieszczeń szpitalnych (Kolarczyk, Kubiak i Wierzbicki 1984, s. 175). Kobiety i mężczyźni uczestniczyli w tych samych nabożeństwach, ale byli odseparowani, pozbawieni możliwości bezpośredniego kontaktowania. Dla niektórych sposobność tylko wzrokowego kontaktu z kobietą była jedynym bodźcem do udziału w nabożeństwie (Pawlak 2008, s. 129-138).

Warto podkreślić, że w okresie międzywojennym zauważa się nie tylko konieczność odmiennego traktowania kobiet i mężczyzn przebywających w warunkach izolacji penitencjarnej, jako że widoczna staje się również zmiana sposobu postrzegania więźniarek - kobiety przestają być uznawane za jednorodną, homogeniczną populację skazanych. Dostrzega się bowiem te będące w ciąży i karmiące, szczególnie w zakresie karania dyscyplinarnego. Wobec nich nie wolno stosować zmniejszenia porcji żywnościowej, postu o chlebie i wodzie, pozbawienia pościeli na czas do 1 tygodnia (tzw. twarde łoże), samotnego zamknięcia w odosobnionej celi do tego przeznaczonej, zamknięcia w ciemnej celi na czas do 48 godzin (art. 53 - Rozporządzenie Prezydenta Rzeczypospolitej z dnia 7 marca 1928 roku w sprawie organizacji więziennictwa). Różnicowanie kobiet znalazło także odzwierciedlenie w zakresie sposobu osadzania w celach mieszkalnych. Wskazywano bowiem, że matki wraz ze swoimi dziećmi nie mogły być osadzone w jednej celi ze skazanymi kobietami odbywającymi karę za uprawianie nierządu (Migdał, Raglewski 2005, s. 137).

W okresie dwudziestolecia międzywojennego w przepisach uwzględniano płeć, różnicując wyposażenie kobiet w bieliznę i odzież. Do podstawowego wyposażenia kobiety w tym zakresie należały: kaftanik wierzchni, spodnie, 2 spódnice, chustka na głowę, chusteczka do nosa, fartuch, koszula, majtki, pończochy, para obuwia (Gordon 2005, s. 478). Ubiór był skromny i mało kolorystyczny. W czasie przebywania w celach więźniarki musiały gładko zaczesywać włosy, a poza izbami więziennymi były zobligowane do noszenia chust na głowach $(\$ 121, \S 132$, §289 - Rozporządzenie Ministra Sprawiedliwości z dnia 20 czerwca 1931 roku w sprawie regulaminu więziennego).

W żeńskich więzieniach pracował przede wszystkim personel żeński. Dozorczynie wykonywały taką samą pracę jak dozorcy, w oparciu o takie same przepisy, nie miały jednak uzbrojenia typowego dla dozorcy. Wyłącznie dozorczynie mogły dokonywać rewizji osobistych kobiet (tamże, s. 479), co było zgodne z zasadą, że kontroli osobistej dokonuje funkcjonariusz tej samej płci. 
Jak wspominałam wyżej, w ramach wykonywania kary pozbawienia wolności zaczęto wyodrębniać kobiety oraz pełnione przez nie role społeczne, co znalazło wyraz w postępowaniu wykonawczym. Matki wraz z dziećmi umieszczano w odrębnych oddziałach. Według ówczesnych przepisów dziecko mogło przebywać z matką do 18 miesiąca życia. Po tym okresie było oddawane rodzinie lub organom opieki społecznej. Generalnie jednak zakazywano przyjmowania i pozostawiania w więzieniach dzieci powyżej 2 roku życia. W drodze wyjątku te, które ukończyły 18 miesiąc po uzyskaniu specjalnego zezwolenia Ministra Sprawiedliwości, mogły być przyjęte razem $\mathrm{z}$ rodzicem do więzienia lub pozostawać w nim dłużej.

Brzemienne więźniarki, począwszy od 7 miesiąca ciąży do 2 miesięcy po porodzie, były zwolnione od obowiązku pracy. Miały gwarancję najwyższych norm kalorycznych i opiekę lekarską. W obowiązujących wówczas przepisach określono również normę żywnościową dla kobiet ciężarnych i brzemiennych na 3000 kcal (art. 31- Rozporządzenie Prezydenta Rzeczypospolitej z dnia 7 marca 1928 roku w sprawie organizacji więziennictwa). Do czasu zapisu regulaminu sformułowanego w 1931 roku norma żywnościowa była dla kobiet o $20 \%$ niższa niż mężczyzn, później je zrównano. W czasie 2 tygodni przed rozwiązaniem kobiety przebywały w specjalnych salach porodowych i pozostawały tam przez 2 tygodnie po porodzie. Istniała możliwość ubiegania się o uzyskanie przerwy w odbywaniu kary i urodzenie dziecka w szpitalu poza murami więzienia. Po urodzeniu dziecka przez 6 tygodni kobiecie przysługiwało wolne od pracy. Zgodnie z zapisami regulaminu z 1931 roku nie można było zatrudniać kobiet od 7 miesiąca ciąży do upływu 2 miesięcy po porodzie. W tym miejscu warto wskazać, że praca była głównym środkiem oddziaływania penitencjarnego (Migdał, Raglewski 2005, s. 151). Miała ona charakter przymusowy, dolegliwy. Jedną z kar zawartych w katalogu było zwiększenie ilości pracy przymusowej. Zajęcie traktowano jako podstawowy środek poprawczy, bowiem praca miała wdrożyć do aktywnego życia oraz - przez zdobycie określonych kwalifikacji zawodowych - zapewnić warunki egzystencji po zwolnieniu z więzienia (Czerwiec 1958, s. 220). Starano się zatrudniać jak największą liczbę skazanych. Praca była odpłatna. Zatrudnienie w latach 1919-1924 kształtowało się na poziomie 20,3\% (tamże, s. 21). Przy wyznaczaniu do pracy uwzględniano rodzaj kary, termin jej zakończenia, stan zdrowia, wiek, płeć, brzemienność, stopień wykształcenia (art. 21 - Rozporządzenie Prezydenta Rzeczypospolitej z dnia 7 marca 1928 roku w sprawie organizacji więziennictwa). W 1925 roku Departament Karny Ministerstwa Sprawiedliwości w wytycznych wydanych funkcjonariuszom w zakresie zatrudniania nakazał brać do uwagę 
płeć - kobiet nie należało zatrudniać w ślusarni, kuźni. Więźniarki przebywające w zakładach karnych w Fordonie, Warszawie czy Wilnie w ramach pracy przede wszystkim wytwarzały kilimy, koronki i hafty (Pawlak 2008, s. 129-138). W związku z kryzysem, który wystąpił w 1929 roku, zatrudnienie generalnie spadło, ale w 1937 roku przy pracach odpłatnych zatrudniano 448 kobiet. Oprócz pracy miały one możliwość edukacji, ale jedynie na poziomie podstawowym. We wszystkich żeńskich zakładach karnych prowadzono nauczanie na poziomie szkoły podstawowej (Gordon 1990, s. 486).

Okres dwudziestolecia międzywojennego to czas reorganizacji polskiego więziennictwa i poszukiwania optymalnego modelu jego funkcjonowania. Po 1924 roku zaczęto organizować nowe typy zakładów. Więzienia podzielono na zwykłe i specjalne (o surowym charakterze resocjalizacyjnym). Większość kobiet odbywała karę w więzieniach zwykłych. Uruchomiono dla nich jeden zakład o zaostrzonym rygorze w Bojanowie koło Rawicza, który mógł pomieścić 100 osób. W 1938 roku przebywało tam 46 osób. Zgodnie z przeznaczeniem tych więzień kobiety odbywające tam karę musiały być, w ocenie sądu, niebezpieczne lub notorycznie dopuszczające się przestępstw. To sąd bowiem wydawał postanowienie o umieszczeniu więźnia w tego typu zakładzie (Pawlak 2008, s. 129-138). W tych placówkach, przez okres 5 lat po odbyciu ostatniej kary, przebywały wielokrotne recydywistki, stwarzające poważne zagrożenie. Drugim typem zakładów dla kobiet były kolonie rolne, które miały charakter resocjalizacyjny. W nich karę odbywały kobiety pierwszy raz skazane wyrokiem do 5 lat, w wieku do 30 lat, mieszkające na wsi i pracujące na roli. Uruchomiono w 1936 roku jedną taką kolonię żeńską w Walendowie pod Warszawą (Migdał 2012, s. 144), którą prowadziły siostry Magdalenki. Z uwagi na brak zabezpieczeń oraz nieuzbrojonych funkcjonariuszek przeprowadzano selekcję kobiet przed ich skierowaniem do tej kolonii. Odbywała się ona w oddziale obserwacyjno-rozdzielczym - jedynym funkcjonującym przy ul. Dzielnej w Warszawie (tamże, s. 146), w którym na podstawie indywidualnego badania zdiagnozowano predyspozycje więźniarek do pobytu w kolonii rolnej. W Walendowie przebywało 48 młodych kobiet, które latem pracowały, a zimą się uczyły.

W latach dwudziestych XX wieku rozpoczęto organizowanie specjalnych leczniczych zakładów penitencjarnych. Żeński szpital psychiatryczny powstał w Grudziądzu w 1933 roku. Cztery lata później przebywało w nim 39 skazanych kobiet ujawniających zaburzenia psychiczne. 


\section{Zakończenie}

Odzyskanie w 1918 roku przez Polskę niepodległości było początkiem zmian $\mathrm{w}$ wielu obszarach funkcjonowania państwa, w tym również $\mathrm{w}$ więziennictwie, które przez 123 lata funkcjonowania w ramach trzech różnych państw zaborczych wymagało ujednolicenia. Kobiety odbywające karę pozbawienia wolności w okresie dwudziestolecia międzywojennego miały takie same prawa jak mężczyźni, chociaż w tworzonych wówczas przepisach dotyczących organizacji więziennictwa wskazuje się na odrębność wykonywania kary pozbawienia wolności wobec nich przede wszystkim w zakresie karania dyscyplinarnego, sposobu rozmieszczania w celach mieszkalnych, wyżywienia, zatrudnienia, sposobu traktowania ciężarnych i karmiących. Funkcjonujące wówczas uregulowania dotyczące więźniarek należy potraktować jako prekursorskie, gdyż zapoczątkowały proces odrębnego traktowania w więzieniu osób ze względu na płeć.

\section{Bibliografia}

Bugajski Z., Neymark E. (2005), Aktualne zagadnienia i projekty reformy więziennictwa, [w:] J. Migdal, J. Raglewski (red.), Kara pozbawienia wolności. Zarys dziejów polskiej doktryny, prawa i praktyki penitencjarnej, Gdańsk: Wydawca ARCHE.

Car S. (1997), Dziesięciolecie więziennictwa polskiego, [w:] K. Urbański (red.), System penitencjarny II Rzeczypospolitej a więźniowie polityczni, Kielce: Kieleckie Towarzystwo Naukowe.

Czerwiec M. (1958), Więzienioznawstwo. Zarys rozwoju więziennictwa, Warszawa: Centralny Zarząd Więziennictwa.

Gordon M. (1990), Postępowanie ze skazanymi kobietami, [w:] A. Marek (red.), Księga jubileuszowa więziennictwa polskiego 1918-1988, Warszawa: Wydawnictwo Prawnicze.

Janicki K. (2013), Upadłe damy II Rzeczpospolitej. Prawdziwe historie, Kraków: Społeczny Instytut Wydawniczy ZNAK.

Migdał J. (2011), Polski system penitencjarny w latach 1918-1928, Gdańsk: Wydawca ARCHE.

Migdał J. (2012), Polski system penitencjarny w latach 1928-1939, Gdańsk: Wydawca ARCHE.

Migdał J., Raglewski J. (2005), Kara pozbawienia wolności. Zarys dziejów polskiej doktryny, prawa i praktyki penitencjarnej, Gdańsk: Wydawca ARCHE.

Rabinowicz L. (1984), Struktura przestępczości w Polsce w świetle statystyki sądowej, [w:] T. Kolarczyk, J. R. Kubiak, P. Wierzbicki, Przestępczość kobiet. Aspekty kryminologiczne i penitencjarne, Warszawa: Wydawnictwo Prawnicze. 
Pawlak K. (1990), Organizacja polskiego więziennictwa, [w:] A. Marek (red.), Księga jubileuszowa więziennictwa polskiego 1918-1988, Warszawa: Wydawnictwo Prawnicze.

Pawlak K. (1995), Więziennictwo polskie w latach 1918-1939, Kalisz: Centralny Ośrodek Szkolenia Służby Więziennej w Kaliszu.

Pawlak K. (2008), Wykonanie kary więzienia i aresztu wobec kobiet w II Rzeczpospolitej, „Przegląd Więziennictwa Polskiego”, nr 58.

Pietrzak M., (2000), Sytuacja prawna kobiet w II Rzeczpospolitej, [w:] A. Żarnowska, A. Szwarc (red.), Kobiety w Polsce międzywojennej. Równe prawa i nierówne szanse, Warszawa: Wydawnictwo „DiG”.

Urbański K. (1997), System penitencjarny II Rzeczypospolitej a więźniowie polityczni, Kielce: Kieleckie Towarzystwo Naukowe.

\section{Akty prawne}

Rozporządzenie Prezydenta Rzeczypospolitej z dnia 7 marca 1928 roku w sprawie organizacji więziennictwa, (Dz. Ustaw poz. 271, 272).

Rozporządzenie Ministra Sprawiedliwości z dnia 20 czerwca 1931 r. w sprawie regulaminu więziennego (Dz.U.R. P. Nr 29, poz. 272).

Dekret w sprawie tymczasowych przepisów więziennych (Dz. Praw nr 15 z dnia 8 lutego 1919 r. poz. 202).

Rozporządzenie Prezydenta Rzeczypospolitej z dnia 11 lipca 1932 r. - Kodeks karny (Dz.U. 1932 nr 60 poz. 571). 
